\title{
THE VALUE OF HIGH-RESOLUTION ANOSCOPY IN THE DIAGNOSIS OF ANAL CANCER PRECURSOR LESIONS IN HIV-POSITIVE PATIENTS
}

\author{
Felicidad GIMENEZ1', Ivan Tramujas da COSTA-e-SILVA², \\ Adriana DAUMAS ${ }^{2}$, José de ARAÚJ0 ${ }^{3}$, Sara Grigna MEDEIROS ${ }^{4}$ and Luiz FERREIRA ${ }^{5}$
}

\begin{abstract}
Context - Anal cancer, although a still rare disease, is being observed in ascending rates among some population segments known to be at risk for the development of the disease. Human papillomavirus (HPV) infection, immunodepression and anal intercourse are some factors associated with the development of the malignancy. Its similarities to cervical cancer have led to many studies aiming to establish guidelines for detecting and treating precursor lesions of anal cancer, with the goal of prevention. Highresolution anoscopy is routinely used for the diagnosis of anal cancer precursor lesions in many centers but the medical literature is still deficient concerning the role of this diagnostic modality. Objectives - To evaluate diagnostic validation and precision measures of high-resolution anoscopy in comparison to histopathological results of anal biopsies performed in HIV-positive patients treated at the Tropical Medicine Foundation of Amazonas, AM, Brazil. To observe any possible association between some risk factors for the development of anal cancer and the presence of anal squamous intraepithelial lesions. Methods - A hundred and twenty-eight HIV-positive patients were submitted to anal canal cytological sampling for the detection of HPV infection by a PCR based method. High-resolution anoscopy was then performed after topical application of acetic acid 3\% in the anal canal for 2 minutes. Eventual acetowhite lesions that were detected were recorded in respect to location, and classified by their tinctorial pattern, distribution aspect, relief, surface and vascular pattern. Biopsies of acetowhite lesions were performed under local anesthesia and the specimens sent to histopathological analysis. The patients were interviewed for the presence of anal cancer risk factors. Results - The prevalences of anal HPV infection and of anal squamous intraepithelial lesions in the studied population were, respectively, $79 \%$ and $39.1 \%$. High-resolution anoscopy showed sensibility of $90 \%$, specificity of $19.23 \%$, positive predictive value of $41.67 \%$, negative predictive value of $75 \%$, and a kappa coefficient of 0.076 . From the analyzed lesions, high-grade squamous intraepithelial lesions was more frequently observed in association to dense (68\%), flat (61\%), smooth (61\%), non-papillary ( $83 \%)$ and normal vascular pattern (70\%) acetowhite lesions, while low-grade squamous intraepithelial lesions tended to be associated to dense (66\%), flat-raised or raised $(68 \%)$, granular (59\%), non-papillary $(62 \%)$ and normal vascular pattern $(53 \%)$ acetowhite lesions. No statistical significance was observed as to the association of epidemiological characteristics and of most of the investigated anal cancer risk factors and presence of acetowhite lesions or anal squamous intraepithelial lesions. However, anal receptive sex and anal HPV infection were significantly associated to anal squamous intraepithelial lesions ( $P=0.0493$ and $P=0.006$, respectively). Conclusion - High-resolution anoscopy demonstrated to be a sensitive, but not specific test for the detection of anal squamous intraepithelial lesions. Risk factors anal receptive sex and anal HPV infection were significantly associated to the presence of anal squamous intraepithelial lesions. Based on high-resolution anoscopy image data, acetowhite lesions relief and surface pattern were prone to distinguish between low-grade squamous intraepithelial lesions and high-grade squamous intraepithelial lesions.
\end{abstract}

HEADINGS - Anus neoplasms. HIV. Papillomavirus infection. Proctoscopy.

This research was developed at the Tropical Medicine Foundation of Amazonas, Manaus, AM, Brazil

This research was supported by the National Program of DST-AIDS, Ministry of Health of Brazil - UNESCO (grant 914BRA1101).

Conflict of Interest: none

1 Getulio Vargas University Hospital, Federal University of Amazonas; ${ }^{2}$ Division of Clinical Surgery, Federal University of the Amazonas; ${ }^{3}$ Pathological Anatomy Department Tropical Medicine Foundation of Amazonas; ${ }^{5}$ Federal University of Amazonas; ${ }^{6}$ Department of Pathology and Forensic Sciencies, Federal University of Amazonas, Manaus, AM, Brasil

Correspondence: Dr. Felicidad Santos Gimenez - Rua Afonso Pena, 589 - Praça 14 -69033-720 - Manaus, AM, Brasil. E-mail: felicidadgimenez@yahoo.com.br 


\section{INTRODUCTION}

Anal cancer has a low incidence corresponding to $1.5 \%$ of all tumors detected in the digestive tract in the United States $^{(42)}$. In Brazil, according to the National Institute of Cancer (INCA), the incidence of anal cancer is reported in association to the incidence of colorectal cancer. In 2009, $4.24 \mathrm{men} / 100,000$ and 4.44 women/100,000 were reported to have colorectal cancer in the state of Amazonas. This type of cancer is ranked as the 4th most detected type in Brazil, and 6th in the north of Brazil ${ }^{(4)}$.

The number of new cases of cancer has significantly increased in distinct groups of population, defined as groups at risk to develop the malignancy ${ }^{(28)}$. They are composed of either immune compromised individuals or individuals engaged in recognized risky activities, namely participation in anal receptive intercourse (especially males) ${ }^{(9,10,33,40)}$, immunosuppressed transplanted patients ${ }^{(36)}$, individuals with a history of sexually transmitted diseases (STD $)^{(5,24,25,30)}$, women presenting a history of cervical cancer or of cervical, vulvar or vaginal squamous intraepithelial lesions ${ }^{(10)}$, individuals with chronic anal inflammation due to fistulas, fissures and hemorrhoids ${ }^{(40)}$, tobacco smokers ${ }^{(16)}$, and individuals with anal cancer due to genetic factors ${ }^{(14)}$.

Among STD, the human papillomavirus (HPV) is well known for causing epithelial proliferative lesions and, based on its oncogenic potential, to evolve into benign warts or highgrade lesions that can turn to skin and mucous malignant tumors ${ }^{(31,50)}$.

HPV infection and development of precursor lesions of cervical cancer generally occur in the transformation zone (squamocolumnar junction) of the uterine cervix. Similarly, the anal transitional zone corresponds to the junction of the anal stratified squamous epithelium to the glandular epithelium of the rectum ${ }^{(27)}$, an area where HPV infects cells of the basal layer of the epithelium through micro lesions ${ }^{(12)}$. Cell and tissue atypical changes in the anogenital area are called anal squamous intraepithelial lesions (ASIL), which, according to the oncogenic potential of the resident HPV type, may or may not evolve into anal cancer ${ }^{(45)}$.

The incidence in the number of cases of cervical cancer has been reduced from $40 / 100,000$ to $8 / 100,000$ in countries where cervical cancer precursor lesions are routinely monitored ${ }^{(41)}$. Based on similarity between ASIL and cervical precursor lesions, a similar routine has been proposed for diagnosing pre-cancerous anal lesions ${ }^{(29)}$. Consequently, a cytology test equivalent to the Pap smear to diagnose cervical cancer is also used to diagnose anal lesions. However, even though this test is efficient, inexpensive ${ }^{(44)}$ and highly sensitive $(98 \%)$ to detect cellular alterations, it has low specificity $(50 \%)^{(37)}$. So in cases of anal cell changes with signs of dysplasia of any magnitude, tend to indicate the use of anuscopy with magnified a procedure similar to cervical ${ }^{(8,23)}$.

In this example, it is observed, with special attention, the squamocolumnar transition zone after topical application of acetic acid 3\%, lesions suspected to be produced by the cytopathic effect of HPV will become whitish and underwent biopsy ${ }^{(26)}$. The histopathological result of a high resolution anoscopy (HRA) monitored biopsy is considered the goldstandard test for confirming the presence of an anal squamous intraepithelial lesion ${ }^{(35,43)}$.

However, even though HRA is a tool routinely used in the diagnosis of anal lesions, there is little information in the medical literature regarding the success of this medical diagnostic technique regarding the detection of anal cancer precursor lesions.

This study was designed to investigate the importance of high-resolution anoscopy as a diagnostic tool to recognize anal lesions associated to ASIL, in order to validate its utilization in the continuous monitoring program of HIV-positive patients treated at Tropical Medicine Foundation of Amazonas (FMTAM), Manaus, AM, Brazil, a population sub-group that has a well-known high potential to develop anal cancer precursor lesions. The research will also evaluate in the population sample treated at the institution: 1) the association among the presence of risk factors for the development of anal cancer and the findings of acetowhite lesions (AWL) at HRA and of ASIL at histopathological analyses; 2) the association between the histopathological results that followed HRA monitored biopsies and the presence of HPV anal infection, according to PCR analysis; and 3) the prevalence of ASIL and HPV infection in the studied population.

\section{METHODS}

After approval at the Ethics in Research Committee of FMT-AM, a primary transversal descriptive diagnostic study was performed in $128 \mathrm{HIV}$-positive patients of both genders seen in the coloproctology outpatient clinic of the institution. All the patients signed an informed consent agreement.

After anal canal cytological sampling for the performance of a PCR based HPV detection test according to the method described by Bauer and Manos ${ }^{(2)}$, patients were submitted to HRA, by three colorectal surgeons (FSG, ITCS, AGDPG), after topical application of 3\% acetic acid, in the anal canal, for 2 minutes. Observed AWL had their location, tinctorial characteristics (acetowhite negative, tenuous or dense), aspect (focal or coalescent), relief (flat, slightly elevated, or elevated lesions), surface (smooth or granular; papillary or nonpapillary), as well as vascular profile (normal or atypical; warty vessels or no warty vessels, punctation or no punctation, mosaicism or no mosaicism) documented according to a modified version of the Barcelona classification (2002) ${ }^{(49)}$. Biopsies of AWL were performed for histopathological analysis under local anesthesia. When no AWL was observed, biopsies were performed in a standardized location (just above the pectinate line at the 7 o'clock position, considering 12 o'clock the anterior commissure).

The histopathological results of the anal biopsies were classified as: negative (including benign inflammatory alterations), low-grade squamous intraepithelial lesions (LSIL, including anal condyloma) or high-grade squamous intraepithelial lesions (HSIL) ${ }^{(3)}$. 
The criteria investigated to define groups at risk to develop anal cancer were as follows: report of anal receptive intercourse, number of sexual partners in the last 5 years, age at which individuals became sexually active, actual and past patient information for STD, HPV infection status, T CD4+ lymphocyte levels below 200 cell $/ \mu \mathrm{L}$, use of antiretroviral therapy (HAART), presence of benign concomitant diseases, history of smoking and of drug addiction.

Data were evaluated in contingency tables in which values were statistically analyzed by Pearson's chi-square test or Fisher's exact test. Independent variables such as age were analyzed by the Mann-Whitney U test. Agreement between the presence of AWL at HRA and the histopathological diagnosis of ASIL was evaluated by kappa statistics interpreted according to Landis and Koch criteria $(<0.00=$ poor; 0.00 $0.20=$ weak; $0.21-0.40=$ regular; $0.41-0.60=$ moderate; $0.61-0.80=$ strong; $0.81-1.00=$ almost perfect).

Significance level values of 0.05 and confidence intervals of $95 \%$ were established for all analysis.

\section{RESULTS}

Table 1 shows the distribution of HIV-positive patients as to receptive anal sex, number of sexual partners in the last 5 years, onset of sexual activity, presence or history of STD and HPV infection in relation to the presence of ACW lesions and ASIL.

Table 2 correlates CD4 cells counts, use of highly-active antiretroviral therapy, presence of concomitant benign diseases, smoking and illicit drug addiction with the presence of ACW lesions and ASIL in HIV-positive patients.

Table 3 depicts the diagnostic validation and precision measures of high-resolution anoscopy obtained in this study in comparison to the gold-standard histopathology.

Table 4 denotes the phenotypic characteristics of HRA of HIV-positive patients, relative to the results of the histopathological analyses of the anal biopsies performed after topical application of 3\% acetic acid.

Table 5 correlates the results of PCR for HPV and histopathological results of anal biopsies performed in HIVpositive patients.

Figures 1 to 6 depict phenotypic HRA characteristics of AWL and indicate their correlation with corresponding PCR for HPV and histopathological findings.

\section{DISCUSSION}

\section{Data analysis of factors involved in anal carcinogenesis}

\section{Acetowhite lesion}

No statistical significance was observed in the correlation between risk factors for anal cancer and the occurrence of AWL $(P>0.05)$ (Tables 1 and 2$)$.

\section{Intraepithelial lesions}

Nevertheless, of 89 patients participating in anal intercourse, 40 presented ASIL (44.94\%) at anal biopsies, while only 10

TABLE 1. Distribution of HIV-positive patients, individuals participating in anal receptive intercourse, number of partners in the last 5 years, age at which individuals became sexually active, actual and past patient information for STD, HPV infection information regarding presence of squamous intraepithelial lesions

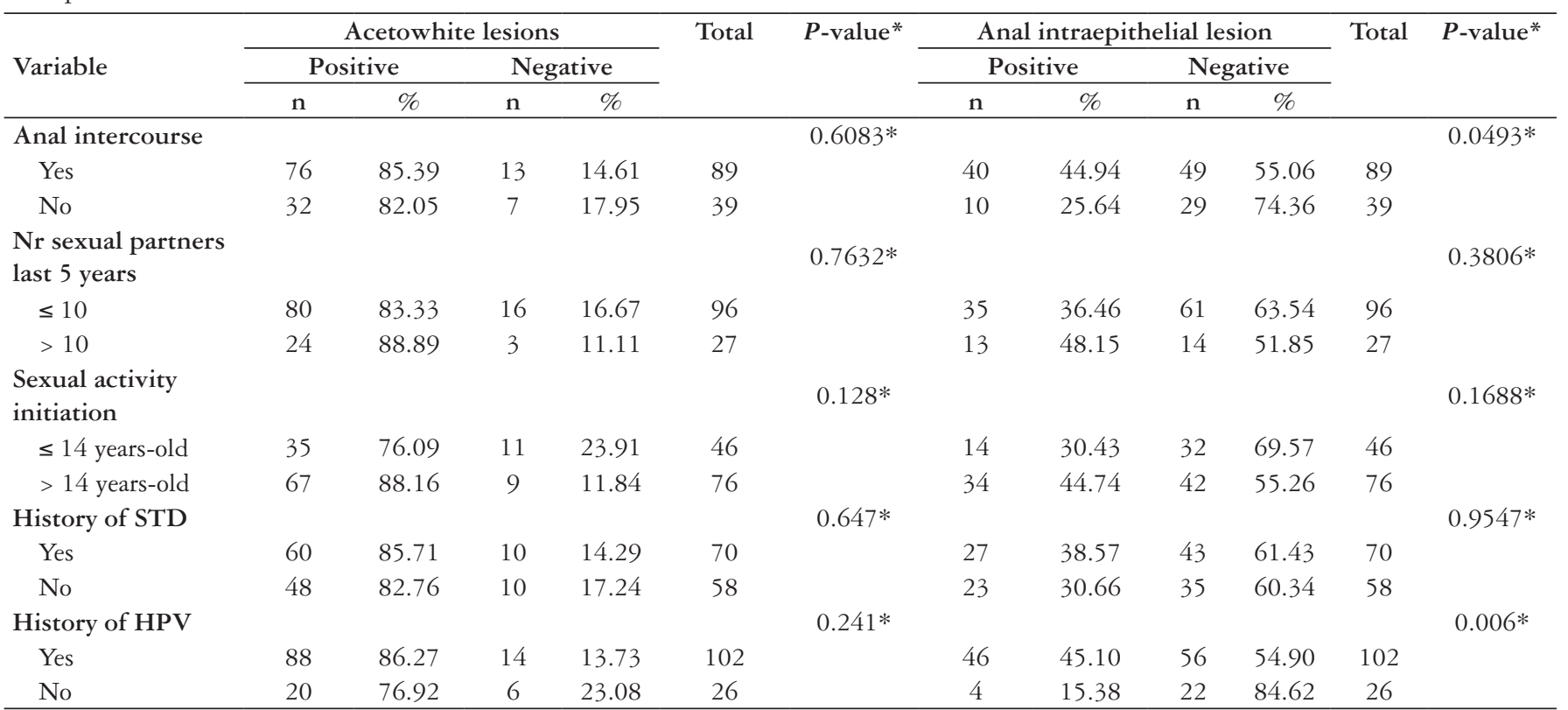

Value in bold indicates $P$-value with statistical difference at the $5 \%$ level

* Pearson's chi-square test or Fisher's exact test 
TABLE 2. Distribution of HIV-positive patients according to T-CD4 cell counts, use of highly active anti-retroviral therapy (HAART), presence of concomitant benign anal diseases, smoking, drug addiction in correlation to high-resolution anoscopy and histopathological findings.

\begin{tabular}{|c|c|c|c|c|c|c|c|c|c|c|c|c|}
\hline \multirow{3}{*}{ Variable } & \multicolumn{4}{|c|}{ Acetowhite lesions } & \multirow[t]{3}{*}{ Total } & \multirow[t]{3}{*}{$P$-value* } & \multicolumn{4}{|c|}{ Anal intraepithelial lesion } & \multirow[t]{3}{*}{ Total } & \multirow[t]{3}{*}{$P$-value* } \\
\hline & \multicolumn{2}{|c|}{ Positive } & \multicolumn{2}{|c|}{ Negative } & & & \multicolumn{2}{|c|}{ Positive } & \multicolumn{2}{|c|}{ Negative } & & \\
\hline & $\mathrm{n}$ & $\%$ & $\mathrm{n}$ & $\%$ & & & $\mathrm{n}$ & $\%$ & $\mathrm{n}$ & $\%$ & & \\
\hline T-CD4 count & & & & & & $0.26 *$ & & & & & & $0.06 *$ \\
\hline$<200 / \mu l$ & 26 & 78.78 & 7 & 21.21 & 33 & & 8 & 24.24 & 25 & 75.76 & 33 & \\
\hline$\geq 200 / \mu l$ & 76 & 87.35 & 11 & 12.64 & 87 & & 38 & 43.68 & 49 & 56.32 & 87 & \\
\hline HAART & & & & & & $0.8423 *$ & & & & & & $0.3134 *$ \\
\hline Yes & 49 & 85.96 & 8 & 14.04 & 57 & & 19 & 33.33 & 38 & 66.67 & 57 & \\
\hline No & 59 & 83.10 & 12 & 16.90 & 71 & & 31 & 43.66 & 40 & 56.34 & 71 & \\
\hline Benign anal diseases & & & & & & $0.3215 *$ & & & & & & $0.8845 *$ \\
\hline Yes & 92 & 85.98 & 15 & 14.02 & 107 & & 42 & 39.25 & 65 & 60.75 & 107 & \\
\hline No & 16 & 76.19 & 5 & 23.81 & 21 & & 8 & 38.10 & 13 & 61.90 & 21 & \\
\hline Smoking & & & & & & $0.3146 *$ & & & & & & $0.513 *$ \\
\hline Yes & 38 & 79.17 & 10 & 20.83 & 48 & & 17 & 35.42 & 31 & 64.58 & 48 & \\
\hline No & 70 & 87.50 & 10 & 12.50 & 80 & & 33 & 41.25 & 47 & 58.75 & 80 & \\
\hline Drug addiction & & & & & & $0.5077 *$ & & & & & & $0.8053 *$ \\
\hline Yes & 22 & 78.57 & 6 & 21.43 & 28 & & 12 & 42.86 & 16 & 57.15 & 28 & \\
\hline No & 86 & 86 & 14 & 14 & 100 & & 38 & 38 & 62 & 62 & 100 & \\
\hline
\end{tabular}

Value in bold indicates $P$-value with statistical difference at the $5 \%$ level

* Pearson's chi-square test or Fisher's exact test

TABLE 3. Diagnostic efficiency of high resolution anoscopy

\begin{tabular}{lclc}
\hline HRA/Pathology & ASIL+* & ASIL-* & Total \\
\hline AWL+* & 45 & 63 & 108 \\
AWL-* & 5 & 15 & 20 \\
Total & 50 & 78 & 128 \\
\hline *AWL+ = positive acetowhite lesions; & & Positive predictive value $=41.67 \%$ & Negative predictive value $=75 \%$ \\
AWL- = negative acetowhite lesions. & & False positive $=89.76 \%$ & \\
ASIL+ = positive histopathology; & & False negative $=10 \%$ & ASIL prevalence $=39.1 \%$ \\
ASIL- = negative histopathology. & & Chi-square test $P=0.2142$ & \\
Accuracy $=46.87 \%$ & Kappa test $=0.076$ &
\end{tabular}

(25.64\%) of those who did not mention anal intercourse activity had the same diagnosis $(P=0.04930)$ (Table 1$)$. Palefsky et al. ${ }^{(29)}$ observed a relationship between ASIL and anal receptive sex in HIV-positive patients. They reported that $50 \%$ of HIV-positive men-who-have-sex-with-men (MSM) in their study presented ASIL. Fox et al. ${ }^{(13)}$ reported ASIL was found in HIV-positive MSM in a prevalence of $26 \%$ and $36 \%$ in two cohort studies undertaken at the USA mainly before the advent of HAART. Gimenez et al. ${ }^{(18)}$ have previously reported a prevalence of ASIL in HIV-positive MSM of $42 \%(P=0.03)$.

Regarding the number of sexual partners in the last 5 years, there was no statistical significance in the correlation with histopathological diagnoses of ASIL of any grade. Thirty-five (36.46\%) individuals who reported having less than 10 partners presented ASIL, while $13(48.15 \%)$ of those that had more than 10 partners also presented the same histopathological finding (Table 1). These results are inconsistent with a study by Frisch et al. ${ }^{(15)}$ in which it was observed that more than 10 sexual partners increased the risk of cancer by 5 times in women and 2.8 times in men. Klencke and Palefsky ${ }^{(22)}$ observed that, in this case, the exposure to various HPV types is the real risk factor to the increasing incidence of ASIL and of anal and cervical cancer observed in these patients.

The average age for first engaging in sexual activity was 14.65 years in the patients studied herein. There was no statistical significance in the correlation between age at which individuals began sexual activity and ASIL. Of 46 patients who began having sex as early as 14 years old, 14 $(30.43 \%)$ were ASIL positive. Seventy-six individuals started having sex after the age of 14; among those, 34 (44.74\%) were ASIL positive (Table 1). In comparison, Frisch et al. ${ }^{(15)}$ observed moderately elevated risk for anal cancer in females who started having sex earlier than 16 years old in comparison to women who first had sexual intercourse after the age of 20 years.

Seventy patients reported an actual or past history of STD; among these, 27 (38.57\%) presented ASIL. Twenty-three $(30.66 \%)$ patients with no STD history presented lesions. Therefore, there was no statistical significance between the 
TABLE 4. Correlation between image characteristics of high-resolution anoscopy and histopathological results

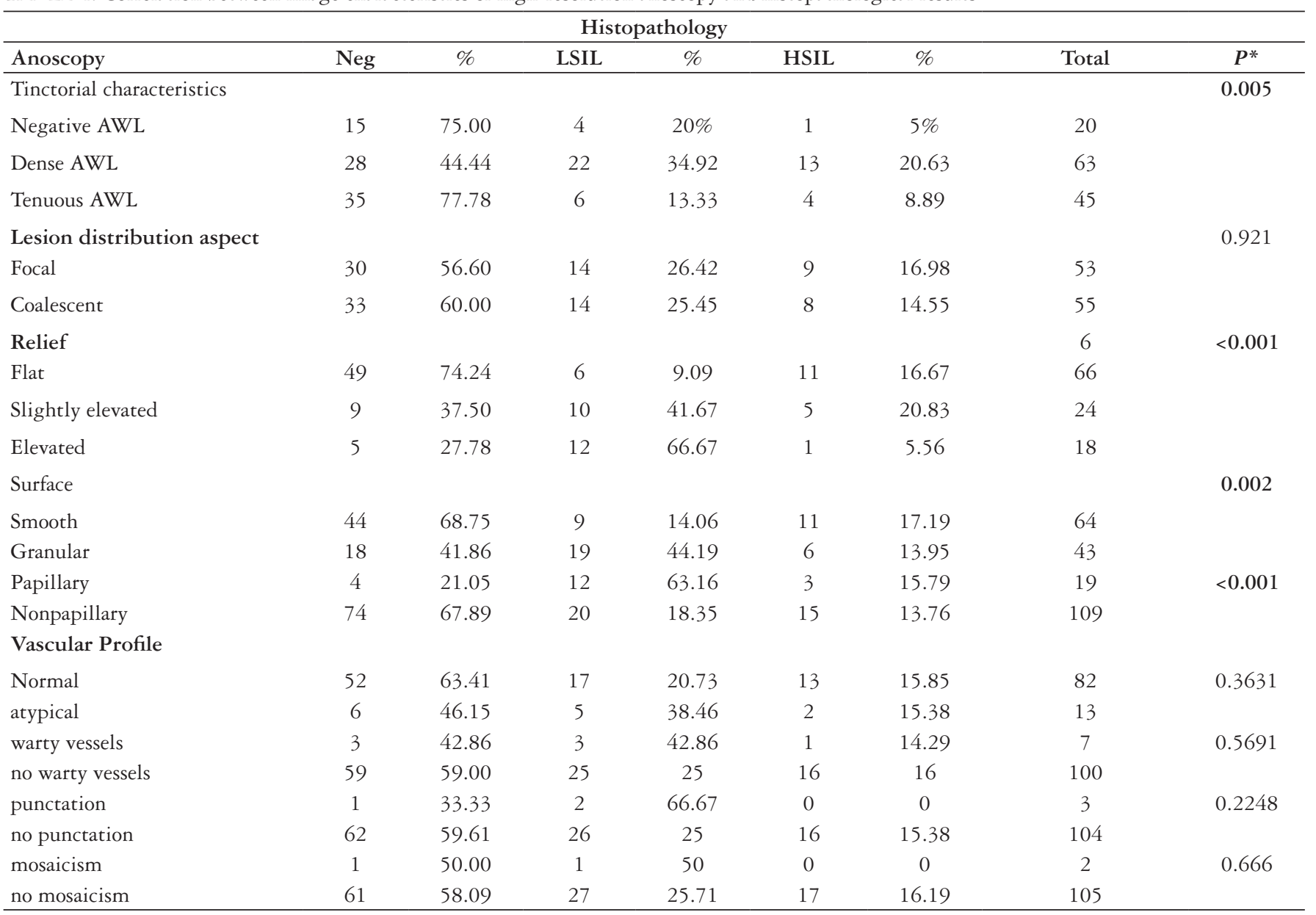

Neg: ASIL negative, including inflammatory alterations, LSIL: low-grade squamous intraepithelial lesion, HSIL: high-grade squamous intraepithelial lesion, AWL: acetowhite lesion

TABLE 5. Correlation between presence of HPV anal infection and anal cancer precursor lesions

\begin{tabular}{|c|c|c|c|c|c|c|}
\hline $\begin{array}{l}\text { PCR/ } \\
\text { histopathology }\end{array}$ & ASIL+ & $\%$ & ASIL- & $\%$ & Total & $P$-value \\
\hline HPV- & 4 & 15.38 & 22 & 84.62 & 26 & \\
\hline
\end{tabular}

$\mathrm{HPV}+$ : presence of HPV, HPV-: absence of HPV.

ASIL+: presence of anal cancer precursor lesion; ASIL-: absence of anal cancer precursor lesion

two groups (Table 1). Regarding anal cancer, Frisch et al. ${ }^{(15)}$ observed a relationship between STD and anal neoplastic development. In 2002, Frisch ${ }^{(17)}$ reported that most STD related to anal cancer were also associated with HPV infection.

Statistical significance was observed between the presence of anal papillomavirus infection, according to PCR results, and ASIL $(P=0.006)$. Forty-six HPV positive patients $(45.10 \%)$ presented ASIL, while only four $(15.38 \%)$ noninfected patients presented lesions (Table 1). Palefsky et al. ${ }^{(32)}$ observed, back in 1998, that nearly all HIV-positive male patients with lymphocytes T-CD4 counts less than $500 / \mathrm{mm}^{3}$ they were following in the city of San Francisco presented PCR detected anal HPV infection. They also reported that $72 \%$ of HIV-positive males with CD4 counts less than $200 / \mathrm{mm}^{3}$ had abnormal anal cytology, so that, taken together, both findings pointed to a probable high prevalence of ASIL in these patients. Indeed, commenting about a work performed by his group in the San Francisco bay to investigate his earlier assumptions and published in 2008, Palefsky states that the prevalence of ASIL of any grade in HIV-positive MSM was 
$57 \%(43 \%$ HSIL) and that HPV infection was detected in $88 \%$ of these patients, $72 \%$ of whom were oncogenic $\mathrm{HPV}^{(34)}$.

Thirty-three of the patients studied herein presented T-CD4 levels below 200 cells $/ \mu \mathrm{L}$, eight $(24.24 \%)$ of those were ASIL positive. Among those patients presenting T-CD4 cells counts above $200 / \mu \mathrm{L}, 38(43.68 \%)$ were ASIL positive, demonstrating no correlation between T-CD4 levels and ASIL (Table 2). The same was observed in patients who were under HAART. Nineteen patients (33.33\%) that received the medication were ASIL positive, while 31 (43.66\%) patients who did not use the medication were also positive for ASIL (Table 2). Abramowitz et al. (1) also observed no correlation in the association of levels of T-CD4 lymphocytes, use of HAART and ASIL. On the other hand, Piketty et al. (38) reported a high prevalence of ASIL (64\%) in patients using HAART when their immunity was restored and Palefsky ${ }^{(34)}$ described an increase in number of cases of anal and cervical cancer despite the use of HAART.

There was also no statistical significance in the association between ASIL and the presence of anal benign diseases (hemorrhoids, hypertrophied papilla, anal fistula, anal fissure, mucosal prolapse, anal pruritus, and proctitis) in the 107 individuals in whom these characteristics were studied. Among these patients, 42 (39.25\%) were positive for ASIL, while 8 of 27 patients $(38.10 \%)$ who did not present any listed disease were also positive (Table 2). These results are not consistent with the findings of Frisch et al. ${ }^{(14)}$ and Tseng et al. ${ }^{(47)}$ who noticed a significant relation between benign anal lesions and anal cancer, although no case of anal cancer was observed among our patients.

Our data did not find any association of smoking with the presence of ASIL. We observed that among 48 smokers, $17(35.42 \%)$ were positive for ASIL, while $70(87.50 \%)$ nonsmokers also presented ASIL (Table 2). Contrarily (considering ASIL a stage of anal cancer development), Tseng at al. ${ }^{(47)}$ reported an association between smoking and anal cancer and Daling et al. ${ }^{(11)}$ showed that smoking was associated with an odds ratio of 3.9 to develop anal cancer.

There was no statistical significance between the presence of ASIL and addiction to hallucinogen drugs. Among drug users, $42.86 \%$ presented intraephitelial lesions, while $38 \%$ of non-drug users also presented ASIL (Table 2). In contrast, Ching-hong et al. ${ }^{(6)}$ reported statistical significance for this factor $(P=0.03)$, while Piketty et al. ${ }^{(37)}$ reported $34 \%$ of cases of ASIL in HPV positive heterosexual individuals using drugs.

\section{Diagnostic accuracy of HRA}

HRA was associated with high sensitivity (90\%) but low specificity $(19.23 \%)$ for the diagnosis of ASIL, with a negative predictive value of $75 \%$ and a low positive predictive value of $41.67 \%$ (Table 3 ). False positive and false negative rates were, respectively, $89.76 \%$ and $10 \%$. Sensitivity and specificity rates of HRA vary greatly in the literature, since this is still a very subjective, as well as user, equipment and other-comorbidity-dependent test ${ }^{(7,19,26,46)}$. Values vary from $59 \%{ }^{(26)}$ to $100 \%{ }^{(46)}$ for sensitivity and from $6 \%^{\circ}{ }^{(46)}$ to $74 \%{ }^{(24)}$ for specificity. However, more concordantly with our results,
Tuon et al. ${ }^{(4)}$ reported for cervical colposcopy, a much more widely employed and studied method, a specificity rate as low as $19 \%$.

Correlating the presence of AWL with the histopathological diagnosis of ASIL, there was no statistical significance between the variables according to the chi-square test $(0.2142)$, whereas the kappa test (0.076) showed low evidence of agreement between the variables. This is possibly a consequence of the fact that lesions such as hypertrophied papillae, hemorrhoids and inflammation in anal canal used to stain positively by acetic acid, a reflection of the 63 acetowhite-positive lesions that were negative for ASIL, as well as due to HRA interpretative differences among three individual observers.

Diagnostic agreement between HRA images and histopathology

Regarding tinctorial quality of HRA a significant relationship was observed relative to the presence of histopathologically confirmed ASIL $(P=0.005)$, for of 20 patients with HRA negative for AWL, $15(75 \%)$ had negative histopathological results, $4(20 \%)$ presented LSIL and $1(5 \%)$ HSIL. Likewise, regarding dense AWL, 28 (44.44\%) of 63 patients had negative histopathological results, $22(34.92 \%)$ presented LSIL and $13(20.63 \%)$ HSIL. On the other hand, of 45 individuals with tenuous AWL, $35(77.78 \%)$ had negative histopathological results, $6(13.33 \%)$ presented LSIL and $4(8.89 \%)$ HSIL. A proportion of HSIL $(72 \%)$ and LSIL $(69 \%)$ lesions were described as dense AWL. Based on the odds ratio, dense AWL were 2.3 times more likely to be an HSIL than a tenuous lesion $(21 \%$ of dense AWL lesions were HSIL compared to $9 \%$ of tenuous AWL lesions). But, accordingly, a dense AWL was 2.7 times more likely to be an LSIL than a tenuous lesion.

Regarding the relief of lesions observed at HRA, flat lesions tended to be mainly negative for ASIL, but HSIL lesions were more frequently flat at HRA than LSIL. While slightly elevated lesions were more often either negative for ASIL or LSIL, elevated lesions tended to be LSIL. These results showed statistical significance $(P<0.001)$. HSIL lesions tended to be significantly more associated to flat AWL than LSIL $(P<0.001)$. A high-grade lesion was 3 times more prone to be flat than to be elevated ( $16 \%$ of flat lesions were HSIL compared to $5 \%$ of elevated lesions). Comparatively, Jay et al. ${ }^{(21)}$ observed that flat lesions were 4 times more frequently associated to HSIL than elevated lesions (39\% of flat lesions were HSIL compared to $9 \%$ of elevated lesions).

When surface aspect was analyzed, smooth lesions were more frequently observed in relation to negative histopathological results, whereas a granular aspect was not prone to be HSIL and a papillary aspect was more frequently associated to low-grade lesions $(P=0.002)$. Among lesions described as smooth, the probability of them being HSIL were 1.2 times higher than being LSIL ( $17 \%$ of HSIL lesions were smoothv compared to $14 \%$ of granular lesions). Jay et al. ${ }^{(21)}$ found that smooth lesions were 2 times more likely to be HSIL than granular lesions 


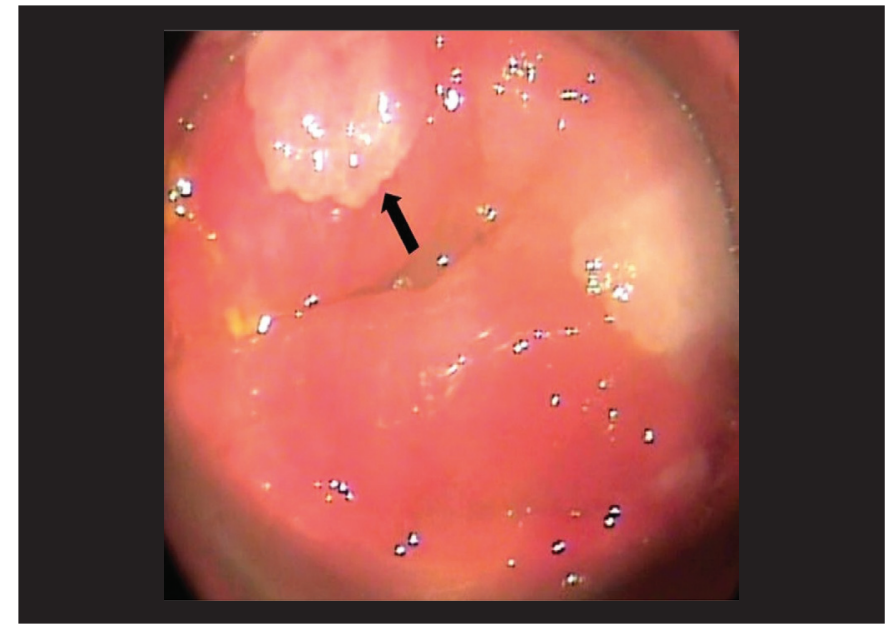

FIGURE 1. Positive acetowhile lesion, dense, focal, flat, smooth, nonpapillary, HPV positive. Histopathology: HSIL

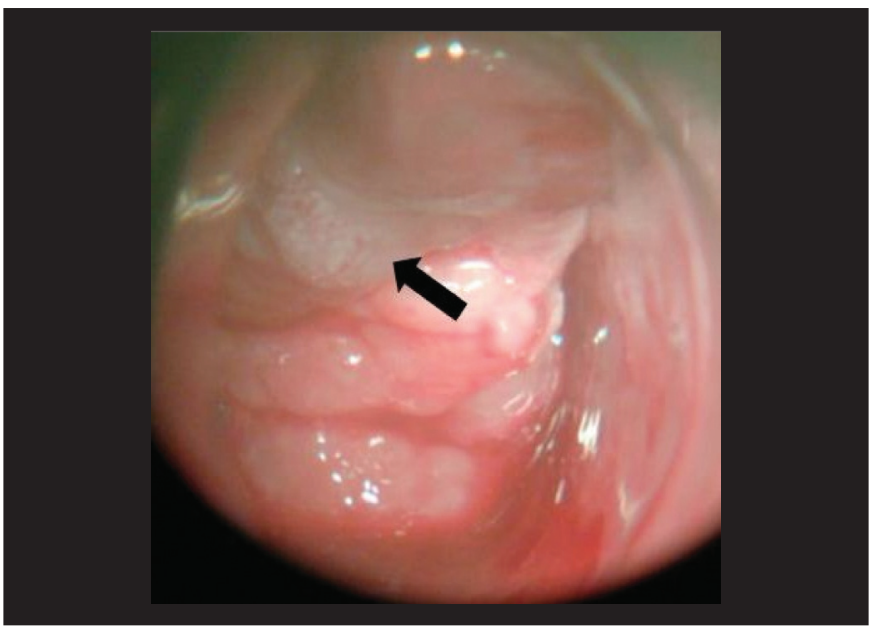

FIGURE 2. Acetowhite lesion dense, coalescent, slightly elevated, papillary, HPV positive. Histopathology: HSIL

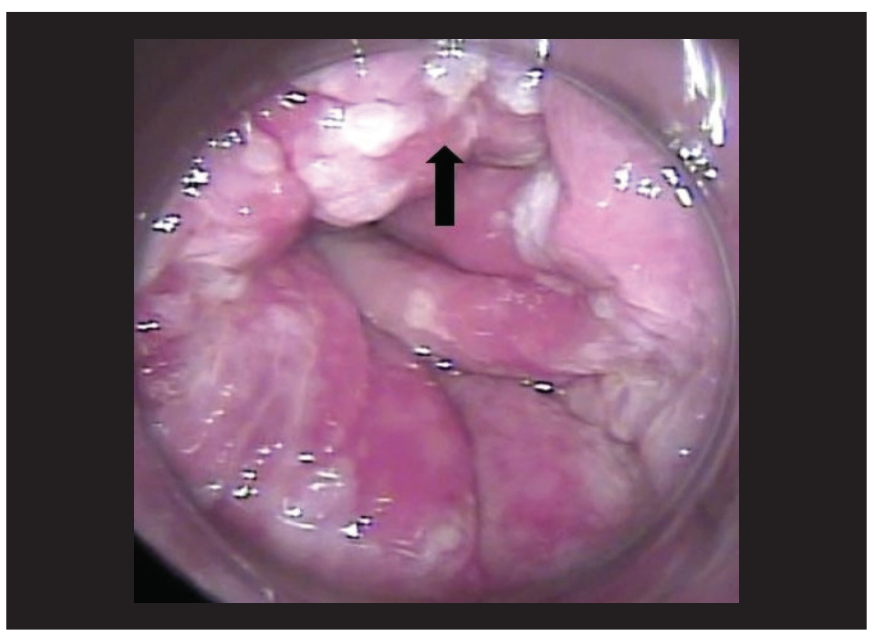

FIGURE 3. Acetowhite lesion, dense, coalescent, slightly elevated, papillary, HPV positive. Histopathology: LSIL

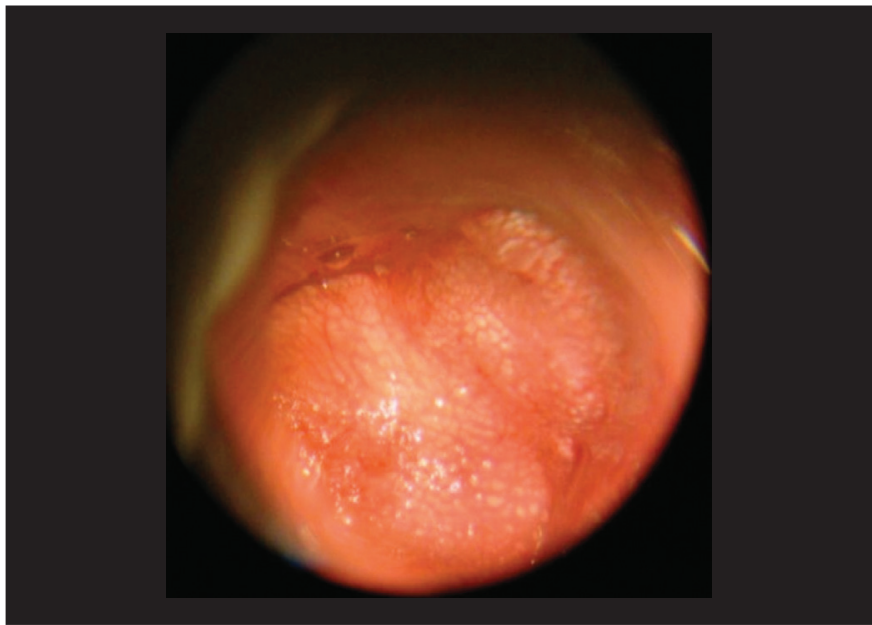

FIGURE 4. Mosaicism, HPV positive. Histopathology: LSIL

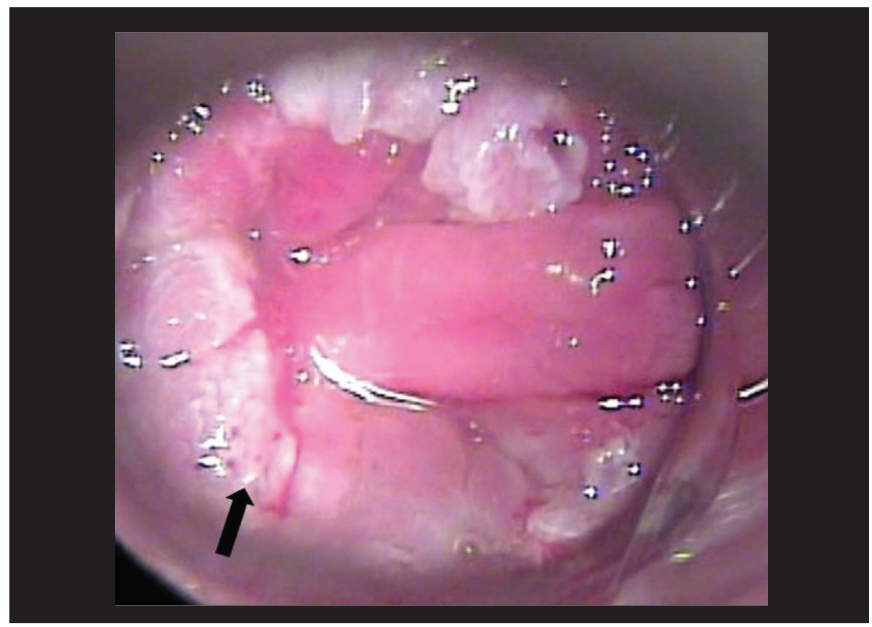

FIGURE 5. Acetowhite lesion dense, coalescent, elevated, granular, punctation, HPV positive. Histopathology: condiloma

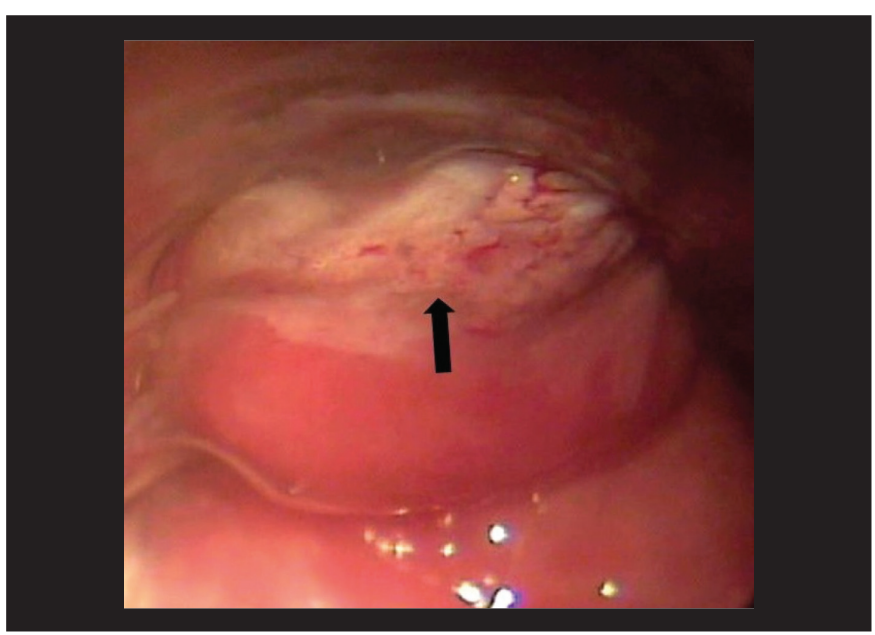

FIGURE 6. Acetowhite lesion dense, slightly elevated, granular, HPV positive. Histopathology: LSIL 
( $31 \%$ of smooth lesions were HSIL compared to $13 \%$ of granular lesions).

Regarding the description of lesions being either papillary or non-papillary, a higher proportion of HSIL $(83 \%)$ than LSIL $(62 \%)$ was described as non-papillary $(P=0.001)$. Non-papillary lesions had a 0.87 times greater chance to be associated to HSIL than LSIL. Jay et al. ${ }^{(21)}$ reported that non-papillary lesions were twice as likely to be HSIL than papillary lesions (34\% of non-papillary lesions were HSIL compared to $14 \%$ of papillary lesions).

There was no statistical significance for the remaining studied aspects of the lesions and their vascular pattern (Table 4), which is not consistent with the findings of Jay et al. ${ }^{(21)}$, in which warty vessels, punctation and mosaicism all presented a statistical significance at the level of 0.001 .

Our data indicate that of the HSIL lesions analyzed 68\% were dense AWL, $61 \%$ were flat, $61 \%$ were smooth, $83 \%$ were non-papillary and $70 \%$ presented a normal vascular pattern. Regarding LSIL lesions, $66 \%$ of them were dense AWL, $68 \%$ were slightly elevated or elevated, $59 \%$ were granular, $62 \%$ were non-papillary and $53 \%$ presented normal vascular pattern.

\section{ASIL prevalence}

Fifty patients were diagnosed as having ASIL (39.1\%) at histopathology: $32(25 \%)$ presented low grade lesions and $18(14.1 \%)$ presented high-grade lesions. These results are similar to other findings in the literature for the prevalence of ASIL, where LSIL ranges from $35.7 \%{ }^{(20)}$ to $42 \%{ }^{(38)}$, while HSIL from $7.1 \%{ }^{(18)}$ to $26 \%(21)$.

\section{HPV prevalence}

The observed HPV prevalence in the HIV-positive patients studied was of $79 \%$. Other similar findings in the literature present prevalence from $80 \%{ }^{(38)}$ to $98 \%{ }^{(39)}$.

\section{Correlation between anal cancer precursor lesions and HPV infection}

Among 50 patients presenting ASIL, 46 were HPV positive, consistent with a $92 \%$ prevalence. Among 32 patients who had LSIL, $30(93.75 \%)$ were HPV positive, while of 18 patients with HSIL, $16(88.88 \%)$ had HPV infection. In a systematic review, 1,824 patients were studied, including 472 and 360 presenting HSIL and LSIL, respectively. The prevalence of HPV in patients presenting HSIL and LSIL was $71.91 \%$ and $88 \%$, respectively ${ }^{(20)}$. Based on the data presented in Table 5 , a prevalence of $45 \%$ of ASIL was observed HIV-positive patients co-infected with HPV.

\section{CONCLUSIONS}

HRA was a highly sensitive method for the detection of ASIL considering the tinctorial quality, relief and surface aspect of AWL which enhanced the capability of distinction between high- and low-grade anal squamous lesions. Nevertheless, due to its poor observed specificity a complementary histopathological study is mandatory in order not to miss unsuspected atypical lesions. The prevalence of anal HPV infection and of ASIL in the studied HIV-positive patients was of, respectively, $79 \%$ and $39.1 \%$ (25\% LSIL and $14.1 \% \mathrm{HSIL}$ ). Anal intercourse and anal HPV infection were highly correlated with the presence of ASIL.

\section{ACKNOWLEDGMENTS}

We are grateful to Rosilene Andrade, Pathologist at the Tropical Medicine Foundation of Amazonas; Junia Raquel Ferreira Dutra, Assistant Professor of the Pharmaceutical Sciences College at the Federal University of Amazonas; and Enrique José Ortellado Rosty, Physician of the Federal University of Amazonas. 
Gimenez F, Costa-e-Silva IT, Daumas A, Araújo J, Medeiros SG, Ferreira L. Anuscopia de alta resolução: valor diagnóstico em lesões precursoras de câncer anal em pacientes soropositivos.. Arq Gastroenterol. 2011;48(2):136-45.

RESUMO - Contexto - O câncer anal, muito embora ainda seja uma doença rara, vem sendo observado com frequência ascendente em alguns grupos populacionais considerados sob risco para o desenvolvimento da doença. Infecção pelo vírus do papiloma humano (HPV), imunossupressão e o sexo anoreceptivo são alguns dos fatores associados ao desenvolvimento da neoplasia. Suas semelhanças com o câncer do colo do útero levaram muitos estudos voltados para o estabelecimento de regras para a detecção e tratamento de lesões precursoras do câncer anal, tudo com o objetivo de prevenir a doença. A anuscopia com magnificação de imagem é rotineiramente utilizada para o diagnóstico de lesões precursoras do câncer anal em muitos centros, mas a literatura médica ainda é escassa a respeito do papel a ser desempenhado por essa modalidade diagnóstica. Objetivos - Avaliar as medidas de validação e precisão diagnósticas da anuscopia com magnificação de imagem em comparação com resultados histopatológicos de biopsias anais realizadas em pacientes HIV-positivos tratados na Fundação de Medicina Tropical do Amazonas, Manaus, AM, Brasil. Observar qualquer possível associação entre alguns fatores de risco para o desenvolvimento do câncer anal e a presença de lesões intraepiteliais escamosas anais. Métodos - Cento e vinte e oito pacientes HIV-positivos foram submetidos a coleta de material celular anal para a realização da detecção da presença de HPV pela reação em cadeia da polimerase. Anuscopias com magnificação de imagem foram realizadas após a aplicação tópica de ácido acético a $3 \%$ no canal anal por 2 minutos. As lesões acetobrancas eventualmente observadas foram registradas com respeito a sua localização e classificadas quanto ao seu padrão tintorial, aspecto de distribuição, relevo, características de sua superfície e vascularidade. Foram realizadas biopsias das lesões acetobrancas sob anestesia local e os espécimes foram remetidos para estudo histopatológico. Os pacientes foram entrevistados em relação à presença de fatores de risco para o câncer anal. Resultados - As prevalências de infecção anal pelo HPV e de lesões intraepiteliais escamosas anais na amostra populacional estudada foram de $79 \%$ e 39,1\%, respectivamente. A sensibilidade e a especificidade da anuscopia com magnificação de imagem foram, respectivamente, de $90 \%$ e $19,23 \%$, enquanto que o valor preditivo positivo foi de $41,67 \%$, o valor preditivo negativo foi de $75 \%$ e o coeficiente kappa de 0,076 . Com respeito às lesões analisadas de alto grau foram mais frequentemente observadas em associação com lesões acetobrancas densas ( $68 \%$ ), planas (61\%), lisas (61\%), não-papilíferas (83\%) e com padrão vascular normal (70\%), enquanto que lesões de baixo-grau tenderam a se associar a lesões aetobrancas densas (66\%), plano-elevadas ou elevadas (68\%), granulares (59\%), não-papilíferas (62\%) e de padrão vascular normal (53\%). Não se observou significância estatística na associação entre características epidemiológicas e a maioria dos fatores de risco para o câncer anal e a presença de lesão acetobrancas ou de lesões intraepiteliais escamosas anais. Entretanto, o sexo anorreceptivo e a detecção de infecção anal por HPV, segundo a técnica da reação da cadeia de polimerase, associaram-se significantemente com lesões intraepiteliais escamosas anais $(P=0,0493$ e $P=0,006$, respectivamente). Conclusões - A anuscopia com magnificação de imagem demonstrou ser um método diagnostico sensível, mas inespecífico para a detecção de lesões intraepiteliais escamosas anais. Os fatores de risco sexo anorreceptivo e infecção anal pelo HPV associaram-se significantemente à presença de lesões intraepiteliais escamosas anais. Com base nos achados da anuscopia com magnificação de imagem, o relevo e o aspecto morfológico da distribuição das lesões acetobrancas na superfície do canal anal tenderam a permitir a distinção entre lesões de baixo e alto grau.

DESCRITORES - Neoplasias do ânus. HIV. Infecções por papilomavírus. Proctoscopia.

\section{REFERENCES}

1. Abramowitz L, Benabderrahmane D, Ravaud P, Walker F, Rioux C, Jestin C, Bouvet E, Soulé JC, Leport C, Duval X. Anal squamous intraepithelial lesions and condyloma in HIV-infected heterosexual men, homosexual men and women: prevalence and associated factors. AIDS. 2007;21:1457-65.

2. Bauer HM, Manos MM. PCR Detection of genital human papillomavirus. In: Persing DH, Smith TF, Tenove FC, White TJ, editors. Diagnostic molecular microbiology principles and applications. Washington D.C.: American Society for Microbiology; 1993. p.407-13.

3. Bethesda System 2001 Terminology. [online]. Bethesda (MD): National Cancer Institute [cited 2005 Sep 29]. Available from: <http://bethesda2001.cancer.gov/ terminology.html>

4. Brasil. Ministério da Saúde. Incidência de câncer no Brasil. Estimativa 2010. Rio de Janeiro: Instituto Nacional do Câncer; 2010

5. Chin-Hong PV, Palefsky JM. Natural history and clinical management of anal human papillomavirus disease in men and women infected with human immunodeficiency virus. Clin Infect Dis. 2002;35:1127-34

6. Chin-Hong PV, Vittinghoff E, Cranston RD, Browne L, Buchbinder S, Colfax G, Da Costa M, Darragh T, Benet DJ, Judson F, Koblin B, Mayer KH, Palefsky JM. Age-related prevalence of anal cancer precursors in homosexual men: the explore study. J Natl Cancer Inst. 2005;97:896-905.

7. Costa-e-Silva IT, Gimenez FS, Fujimoto LBM, Ferreira LCL. Valor da anuscopia com magnificação de imagem no diagnóstico de lesões associadas ao câncer anal [resumo]. In: $55^{\circ}$ Congresso Brasileiro de Coloproctologia. 2006, Rio de Janeiro. Rev Bras Coloproctol. 2006;26:98-9.
8. Coutinho JRH. Rastreamento de lesões pré-neoplasicas do ânus: citologia anal e anuscopia de alta resolução, novas armas para prevenção. Rev Col Bras Cir. 2006:33:311-7.

9. Daling JR, Weiss NS, Klopfenstein LL, Cochran LE, Chow WH, Daifuku R. Correlates of homosexual behavior and the incidence of anal cancer. JAMA. 1982;247:1988-90.

10. Daling JR, Weiss NS, Hislop TG, Maden C, Coates RJ, Sherman KJ, Ashley RL, Beagrie M, Ryan JA, Corey L. Sexual practices, sexually transmitted diseases and the incidence of anal cancer. N Engl J Med. 1987;317:973-7.

11. Daling JR, Madeleine MM, Johnson LG, Schwartz SM, Shera KA, Wurscher MA, Carter JJ, Porter PL, Galloway DA, McDougall JK. Human papillomavirus, smoking and sexual practices in the etiology of anal cancer. Cancer. 2004;101:270-80.

12. Fenger $\mathrm{C}$. The anal transitional zone. Location and extent. Acta Pathol Microbiol Scand A. 1979;87A:379-86.

13. Fox PA. Human papillomavirus and anal intraepithelial neoplasia. Curr Opin Infect Dis. 2006;19:62-6

14. Frisch M, Olsen JH, Bautz A, Melbey M. Benign anal lesions and the risk of anal cancer. N Engl J Med. 1994;331:300-2.

15. Frisch M, Glimelius B, van den Brule AJ, Wohlfahrt J, Meijer CJ, Walboomers JM, Goldman S, Svensson C, Adami HO, Melbye M. Sexually transmitted infection as a cause of anal cancer. N Engl J Med. 1997;337:1350-8.

16. Frisch M, Fenger C, van den Brule AJ, Sorensen P, Meijer CJ, Wallboomers JM, Adami HO, Melbye M, Glimelius B. Variants of squamous cell carcinoma of the anal canal and perianal skin and their relation to human papillomaviruses. Cancer Res. 1999:59:753-7.

17. Frisch M. On the etiology of anal squamous carcinoma. Dan Med Bull 2002;49:194-209. 
18. Gimenez FS, Costa e Silva IT, Guimarães ADP, Ferreira LCL, Araújo JR, Rocha RP, Atala LS, Avi SV, Talhari S. Prevalência de lesões precursoras do câncer anal em indivíduos HIV positivos atendidos na Fundação de Medicina Tropical do Amazonas, experiência inicial em Manaus. Rev Bras Coloproctol. 2008;28:72-6.

19. Hammes LS. Correlação entre achados colposcópicos e diagnóstico histológico segundo a classificação colposcópica da federação internacional de patologia cervical e colposcopia de 2002 [dissertação]. Porto Alegre: Universidade Federal do Rio Grande do Sul; 2004.

20. Hoots BE, Palefsky JM, Pimenta JM, Smith JS. Human papillomavirus type distribution in anal cancer and anal intraepithelial lesions. Int J Cancer. 2009; $124: 2375-83$.

21. Jay N, Berry JM, Hogeboom CJ, Holly EA, Darragh TM, Palefsky JM. Colposcopic appearance of anal squamous intraepithelial lesions: relationship to histopathology. Dis Colon Rectum. 1997;40:919-28.

22. Klencke BJ, Palefsky JM. Anal cancer: an HIV-associated cancer. Hematol Oncol Clin North Am. 2003; 17:859-72.

23. Kuppers V. Significance of colposcopy in cancer prevention. Gynakol Prax. 2005;29:69-86.

24. Martin F, Bower M. Anal intraepithelial neoplasia in HIV positive people. Sex Transm Infect. 2001;77:327-31.

25. Martins CR. HPV-induced anal dysplasia: what do we know and what can we do about it? Hopkins HIV Rep. 2001;133-5.

26. Mathews WC, Sitapati A, Caperna JC, Barber RE, Tugent A, Go U. Measurement characteristics of anal citology, histopathology and high-resolution anoscopic visual impression in an anal dysplasia screening program. J Acquir Immune Defic Syndr. 2004;37:1610-5.

27. Melbye M, Sprogel P. Aetiological parallel between anal cancer and cervical cancer. Lancet. 1991;338:657-9.

28. Nadal RS, Manzione CR. Citologia como método para detecção de lesões precursoras do carcinoma anal. Rev Bras Coloproctol. 2005;25:72-4.

29. Palefsky JM, Holly EA, Hogeboom CJ, Berry JM, Jay N, Darragh TM. Anal cytology as a screening tool for anal squamous intraepithelial lesions. J Acquir Immune Defic Syndr Hum Retrovirol. 1997;14:415-22.

30. Palefsky JM. Human papillomavirus infection and anogenital neoplasia in human immunodeficiency virus-positive men and women. J Natl Cancer Inst Monogr. 1998;(23):15-20.

31. Palefsky JM, Holly EA, Hogeboom CJ, Ralston ML, DaCosta MM, Botts R, Berry JM, Jay N, Darragh TM. Virologic, immunologic, and clinical parameters in the incidence and progression of anal squamous intraephitelial lesions in HIVpositive and HIV-negative homosexual men. J Acquir Immune Defic-Syndr Hum Retrovirol. 1998;17:314-9.

32. Palesky JM, Holly EA, Ralstson ML, Jay N. Prevalence and risk factors for human papillomavirus infection of the anal canal in human immunodeficiency virus (HIV)positive and high-risk HIV-negative homosexual men. J Infect Dis. 1998;177:361-7.

33. Palefsky JM, Holly EA, Ralston ML, Jay N, Berry JM, Darragh TM. High incidence of anal high-grade squamous intraepithelial lesions among HIV-positive and HIV-negative homosexual and bisexual men. AIDS. 1998;12:495-503.

34. Palefsky J. Human papillomavirus-related disease in people with HIV. Curr Opin HIV AIDS. 2009;4:52-6.

35. Panther LA, Wagner K, Proper J, Fugelso DK, Chatis PA, Weeden W, Nasser IA Doweiko JP, Dezube BJ. High resolution anoscopy findings for men who have sex with men: inaccuracy of anal cytology as a predictor of histologic high-grade anal intraepithelial neoplasia and the impact of HIV serostatus. Clin Infect Dis.
2004;38:1490-2.

36. Penn I. Occurrence of cancers in immunosuppressed organ transplant recipients. Clin Transpl. 1998;147-58.

37. Piketty C, Darragh TM, Da Costa M, Bruneval P, Heard I, Kazatchkine MD, Palefsky JM. High prevalence of anal human papillomavirus infection and ana cancer precursors among HIV-infected persons in the absence of anal intercourse. Ann Intern Med. 2003;138:453-9.

38. Piketty C, Darragh TM, Heard I, Da Costa M, Bruneval P, Kazatchkine MD Palefsky JM. High prevalence of anal squamous intaepithelial lesions in HIVpositive men despite the use of highly active antiretroviral therapy. Sex Transm Dis. 2004;31:96-9.

39. Pokomandy A, Rouleau D, Ghattas, G, Vézina S, Coté P, Macleod J, Allaire G, Franco EL, Coutlée F. Prevalence, clearance and incidence of anal human papillomavirus infection in HIV-infected men: the HIPVIRG cohort study. J Infect Dis. 2009;199:965-973.

40. Prieto Reyes M, Vázquez Márquez L. [Anal epidermoid carcinoma: a rare incidence or a rare diagnosis?] Rev Esp Enferm Dig. 1997;2:128-32.

41. Qualters JR, Lee LNC, Smith RA, Aubert RE. Breast and cervical cance surveillance, United State, 1973-1987. MMWR CDC Surveill Summ. 1992;41(2):17.

42. Ryan DP, Compton CC, Mayer RJ. Carcinoma of the anal canal. N Engl J Med. 2000;342:792-800

43. Scholefield JH, Johnson J, Hitchcock A, Kocjan G, Smith JH, Smith PA, Ferryman S, Byass P. Guidelines for anal cytology-to-make cytological diagnosis and follow up much more reliable. Cytopathology. 1998;9:15-22.

44. Silva ITC, Gimenez FS, Guimarães RAS, Camelo RT, Melo MND, Barros FS, Guimarães ADP, Cabral CRB, Guimarães EL. Citologia anal como método de rastreamento para detecção precoce do câncer anal: esfregaços com algodão hidrófilo são mesmos insatisfatórios? Acta Cir Bras. 2005;20:109-114.

45. Spence AR, Franco EL, Ferenczy A. The role of human papillomavirus in cancer: evidence to date. Am J Cancer. 2005;4:49-64.

46. Tramujas da Costa e Silva I, de Lima Ferreira LC, Santos Gimenez F, Gonçalves Guimarães RA, Botinelly Fujimoto L, Barbosa Cabral CR, Venturim Mozzer $\mathrm{R}$, de Souza Atala L. High-resolution anoscopy in the diagnosis of anal cancer precursor lesions in renal graft recipients. Ann Surg Oncol. 2008;15:1470-5.

47. Tseng HF, Morgenstern H, Mack TM, Peters RK. Risk factors for anal cancer results of a population-based case-control study. Cancer Causes Control. 2003; 14:837-46.

48. Tuon FFB, Bittencourt MS, Panichi MA, Pinto AP. Avaliação da sensibilidade e especificidade dos exames citopatológicos e colposcópico em relação ao exame histológico na identificação de lesões intra-epiteliais cervicais. Rev Assoc Med Bras. 2002;48:140-4.

49. Walker P, Dexeus S, De Palo G, Barrasso R, Campion M, Girardi F, Jakob C, Roy M. International terminology of colposcopy: an update report from the International Federation for Cervical Pathology and Colposcopy. Obstet Gynecol. 2003;101:175-77.

50. Zaki SR, Judd R, Coffield LM, Greer P, Rolston F, Evatt BL. Human papillomavirus infeccion and anal carcinoma. Retrospective analysis by in situ hybridization and the polymerase chain reaction. Am J Pathol. 1992;140:1345-55.

Received 20/10/2010 Accepted 12/1/2011. 